\title{
Reminiscence therapy: development of a program for institutionalized older people with cognitive impairment
}

Terapia de reminiscência: construção de um programa para pessoas idosas com declínio cognitivo em contexto institucional

Terapia de reminiscencia: construcción de un programa para personas mayores con deterioro cognitivo en un contexto institucional

Isabel Maria de Assunção Gil; Paulo Jorge dos Santos Costa**; Elzbieta Malgorzata Bobrowicz-Campos***; Daniela Filipa Batista Cardoso****; Maria de Lurdes Ferreira de Almeida*****; João Luís Alves Apóstolo ${ }^{* * * * * *}$

\begin{abstract}
Background: The lack of structured intervention programs aimed at older people with cognitive impairment in Portugal has been identified as one of the main obstacles to the effectiveness of reminiscence therapy (RT) programs in institutional settings. Thus, well-defined and replicable RT programs should be developed and validated to fill in the gap.

Objectives: To develop and validate an RT program.

Methodology: The Medical Research Council framework for the development of complex interventions was followed. The program was developed in four distinct phases, including preliminary phase, modeling, field testing, and consensus conference.

Results: The validation process resulted in a program consisting of a core component and a follow-up component, in a total of 21 sessions for group intervention.

Conclusion: The RT program, which was designed and validated during this study, demonstrated characteristics adjusted to the context and the construct was meaningful to the target population. The effectiveness of the RT program will be tested in a future pilot study.
\end{abstract}

Keywords: cognitive dysfunction; aged; program development; reminiscence therapy

\section{Resumo}

Enquadramento: A ausência, ao nível nacional, de modelos de intervenção estruturados, dirigidos a pessoas idosas com declínio cognitivo, tem sido apontada como um dos principais obstáculos à eficácia da terapia de reminiscência (TR) em contexto institucional. Assim, emerge a necessidade de se desenvolverem e validarem programas de TR bem-definidos e replicáveis, de modo a colmatar a lacuna identificada.

Objetivos: Construir e validar um programa de TR.

Metodologia: Foram seguidas as diretrizes para desenvolvimento de intervençóes complexas do Medical Research Council. A conceptualização do programa decorreu em 4 fases distintas, incluindo fase preliminar, modelagem, Teste de campo e conferência de consensos. Resultados: $O$ processo de validaçáo resultou num programa composto por uma vertente principal e uma vertente de manutenção, num total de 21 sessóes para aplicar em grupo.

Conclusáo: $\mathrm{O}$ programa de TR, estruturado e validado no decorrer deste estudo, demonstrou características ajustadas ao contexto e população-alvo, tendo o construto significado para as pessoas. A eficácia do programa de TR será testada num estudo piloto a ser desenvolvido.

Palavras-chave: disfunção cognitiva; idoso; desenvolvimento de programas; terapia reminiscência

*MSc., Adjunct Professor, Nursing School of Coimbra, 3046-851, Coimbra, Portug [igil@esenfc.pt]. Contribution to the article: literature search and review, and article Cons, Rua da Fonte s/n, 3020-924, Coimbra, Portuga

Porc., Research Grant Holder, Nursing School of Coimbra, 3046-851, Coimbra review, and article writing. review, and article writing,

search Unit: Nursing Portuolder, Nursing School of Coimbra, Health Sciences ReExcellence 3046-851, Coimbra, Portugal [elzbietace-Based Practice: A JBI Centre of to the article: literature search and review, and article writing

to the article: literature search and review, and article writing. tugal [dcardoso@esenfc.pt].Contribution to the article: literature search and review, and article writing

******Ph.D., Coordinating Professor, Nursing School of Coimbra, 3046-851, Coimbra Portugal [mlurdes@esenfc.pt].Contribution to the article: literature search and review, and article writing.

*******Ph.D Coordinating Professor, Nursing School of Coimbra, Health Sciences Research Unit: Nursino Portugal Center for Evidence-Based Practice. A JBI Centre of Excellence, 3046-851, Coimbra Portugal [apostolo@esenf.pt]. Contribution to the article: literature search and review, and article writing.

\section{Resumen}

Marco contextual: La ausencia, a nivel nacional, de modelos de intervención estructurados, dirigidos a personas mayores con deterioro cognitivo, se ha señalado como uno de los principales obstáculos para la eficacia de la Terapia de Reminiscencia (TR) en un contexto institucional. De este modo, surge la necesidad de desarrollar y validar programas de TR bien definidos y replicables para abordar la laguna identificada.

Objetivos: Construir y validar un programa de TR.

Metodología: Se siguieron las directrices para el desarrollo de intervenciones complejas del Medical Research Council. La conceptualización del programa se desarrolló en 4 fases distintas, entre ellas la fase preliminar, el modelado, la prueba de campo y la conferencia de consensos.

Resultados: El proceso de validación dio lugar a un programa compuesto por una vertiente principal y una vertiente de mantenimiento, en un total de 21 sesiones para aplicar en grupo.

Conclusión: El programa de TR, estructurado y validado en este estudio, demostró características ajustadas al contexto y a la población objetivo, por lo que el constructo tiene significado para las personas. La eficacia del programa de TR se probará en un estudio piloto por desarrollar.

Palabras clave: disfunción cognitiva; anciano; desarrollo de programa; terapia reminiscencia

Received for publication: 12.06 .17

Accepted for publication: 28.08.17

Série IV - n. ${ }^{0} 15$ - OUT./NOV./DEZ. 2017 


\section{Introduction}

Data from the Portugal - Saúde Mental em Números 2015 report (Direcção-Geral de Saúde, 2016) indicate that the incidence of mild cognitive impairment among older people aged over 65 years is between $9.9 \%$ and $21.5 \%$, a rate that is expected to triple by 2050 . Older people with cognitive impairment gradually lose their cognitive and motor abilities, which, in more advanced disease stages, causes families to feel overburden, ultimately leading to older people's institutionalization. According to Kuske et al. (2009), approximately 60\% of institutionalized people in industrialized countries have some type of dementia, which has placed new demands for these institutions and their professionals. Therefore, the design of interventions that focus on best practices for active aging to minimize the impact of neurocognitive disorders (NCDs) should be a priority. These interventions will allow delaying or altering the progression of NCDs, thus reducing the associated symptoms (Direcção-Geral de Saúde, 2016; World Health Organization, 2015).

Research has shown the positive impact of the combined use of pharmacological and non-pharmacological therapies in older people with cognitive impairment. Literature describes the privileged role of non-pharmacological interventions in multidimensional models, by integrating the cognitive, functional, behavioral, and affective dimensions. In fact, the significant impact, effectiveness, and health gains obtained through the implementation of structured reminiscence therapy (RT) programs in older people with cognitive impairment are particularly relevant, namely decreased disorientation and depression, and improved well-being and cognitive function (Bohlmeijer, Roemer, Cuijpers, \& Smit, 2007; Subramaniam \& Woods, 2012; Webster, Bolhmeijer, \& Westerhof, 2010).

Evidence shows that RT is an important therapeutic strategy for the empowerment of people with NCDs, providing moments of pleasure with dignity and a purpose in life. RT is a cognitive stimulation technique used to recall old memories with the purpose of triggering past experiences. To this end, RT uses old materials (newspapers, household utensils, photos, songs) to stimulate memory and allow them to share and value their experiences (Subramaniam \& Woods, 2012; Webster et al., 2010). At an international level, the process of development and validation of $\mathrm{RT}$ programs used in controlled studies is not always clearly described, which is a potential methodological limitation that may explain the inconsistent results found in different studies on the effectiveness of RT programs (Bohlmeijer et al., 2007; Cotelli, Manenti, \& Zanetti, 2012; Stinson, 2009). Even in recent studies on the development of a high-quality intervention program (e.g., Stinson, 2009), the process is based on theoretical studies and recommendations which have not been validated regarding compliance and applicability.

In Portugal, evidence on the effectiveness of RT programs is scarce and no studies were found in institutionalized older adults with cognitive impairment. Other authors have used different target populations and interventions. For example, Gonçalves (2006) focused on older people with depressive symptoms, and Lopes, Afonso, and Ribeiro (2013) used individual interventions based on spontaneous memories. However, since none of these studies used standardized RT programs, research in this area calls for the development of a well-structured and replicable program (Berg et al., 2010; Stinson, 2009).

In view of the above, the guidelines and recommendations of the Medical Research Council (Craig et al., 2008) for the development of complex interventions were followed to develop and validate an RT program to be applied to older people with cognitive impairment in institutional settings. This article aims to describe the different stages underlying this process.

\section{Background}

Since no RT program has yet been developed that can be replicated in Portuguese settings, and considering that the lack of consensual structured intervention models may explain the methodological weaknesses that limit the analysis of the effectiveness of RT programs (Gonçalves, Albuquerque, \& Martín, 2008; Cotelli et al., 2012), it was important to deve- 
lop and validate a program of this nature. The Medical Research Council (Craig et al., 2008) introduced the concept of complex intervention, describing it as a number of interactions between components within the experimental and control interventions, the number and difficulty of behaviors required by those delivering or receiving the intervention, a number of groups or organizational levels targeted by the intervention, the variability of outcomes, and the degree of flexibility or tailoring of the intervention permitted. The development of a complex intervention should be based on: identifying existing evidence; identifying and developing theory; and modelling process and outcomes (Craig et al., 2008).

In order to address this emerging social challenge and fill in the identified gaps, an RT program was designed and validated to be applied to older people with cognitive impairment in institutional settings.

\section{Research questions}

Is the RT program developed in this study valid for the population of older people with cognitive impairment in institutional settings?

\section{Methodology}

Given the nature of the topic under analysis, a descriptive study was conducted that focus on the different phases of development and validation of the structured RT program based on the guidelines of the Medical Research Council (Craig et al., 2008): Phase I (preliminary development), which is the first step in the design of a program and corresponding materials; Phase II (modeling), which is supported by interviews and focus groups; Phase III (field testing), which assesses each program session; and Phase IV (consensus conference). This process allows synthesizing the contributions and challenges arising from its multiple phases. With regard to Phase I (preliminary development), in order to identify the strengths and limitations of existing programs, a body of emerging evidence based on primary studies and systematic literature reviews (Berg et al., 2010; Stinson, 2009) were analyzed, with and without meta-analysis. This analysis confirmed the therapeutic potential of RT for the promotion of mental health among older people. The first draft of the program was developed, consisting of a core component (14 sessions) and a follow-up component (7 sessions). A digital platform was also created to collect the necessary audiovisual contents for each session.

Preliminary consultations were also held with health professionals, in a total of seven nurses holding a Master's, Specialization, or Doctoral degree in the areas of Psychiatry and Mental Health and Geriatrics and Elderly Health. The consultation process focused on the acceptability of an RT program to be applied to older people with cognitive impairment in institutional settings. Health professionals were invited to express their views on the relevance and feasibility of such program, while the research team reviewed the literature and compared the evidence with the professionals' opinion, namely regarding the structure, length, content, and dynamics of the planned sessions.

In addition, one of the key moments in this phase was the identification of topics of interest to 40 older people from seven long-term institutions in the center region of Portugal, which focused on the relevance of topics, contents, and activities to be included in the program. The following inclusion criteria were applied in this phase: older people aged 65 years or over, who were institutionalized for 6 months or more, and who scored 20 points or less in the Six-Item Cognitive Impairment Test (6CIT) of Brooke and Bullock (1999), which was adapted to Portugal by Paiva and Apóstolo (2015).

With regard to the Phase II (modeling), two focus groups were held. The first focus group was composed of six nurses with training and experience in conducting therapeutic interventions in institutional settings, and the second one was composed of seven professionals from multidisciplinary nursing areas (mental health, psychiatry, psychology, pedagogy, and gerontology). Both focus groups discussed the need to promote reminiscence-based interventions in institutional settings and analyzed potential barriers to their implementation. The program was made available in advance for the experts to analyze each program session and the digital platform. 
The focus groups were coordinated by the author of the RT program, while another researcher made notes with all comments and suggestions. First, the obtained results were evaluated individually, then they were triangulated and analyzed based on each focus group's opinions. Subsequently, participants were asked to complete an anonymous questionnaire with the purpose of collecting their opinions about the structure, duration, and topics of each session, among others. The answers were rated on a 5-point Likert scale, ranging from strongly disagree to strongly agree. With regard to Phase III (field testing), the data collected during the focus groups were limited to the experts' professional experience, which resulted in the purely theoretical discussion of the RT program. Therefore, the program needed to be more practical, with a core component and a follow-up component (21 sessions in total). This process involved seven nurses working in nursing homes and nine older adults with cognitive impairment (based on 6CIT scores) admitted to a long-term institution in the Center region of Portugal. The main researcher provided nurses with a pre-intervention training on the scope of RT as a therapeutic intervention, the key guiding principles of group reminiscence sessions, and the structure and purpose of the RT program.

The sessions were carried out in a private room at the institution. They were led by two nurses and observed by the researcher, who collected qualitative data on interest, communication, social interaction, and satisfaction from each session based on the observation of the group dynamics and participants' interaction. However, there was a need to document participants' difficulties during a particular activity, as well as nurses' difficulties in conducting the sessions.

To this end, older adults and nurses were asked to complete an anonymous questionnaire with the purpose of collecting their opinions about the structure, duration, topics, content, and organization of the sessions and their potential for replication. The answers were rated on a 5-point Likert scale, ranging from strongly disagree to strongly agree.

During Phase IV (consensus conference), a panel of multidisciplinary experts analyzed and discussed the gathered consensuses. The research team presented the quantitative and qualitative evaluation and the record of all comments and suggestions to the panel of experts. The different versions were compared and the significant changes and potential strengths and limitations of the program were discussed, thus completing this process.

With regard to the ethical and legal principles, it should be noted that the Ethics Committee of the Nursing School of Coimbra authorized the research study and that the procedures carried out throughout the multiple phases complied with the principles of participants' anonymity, consent, and data confidentiality.

\section{Results}

Each phase provided different contributions for the analysis and restructuring of the RT program. The obtained results are described below.

During Phase I (preliminary development), the first draft of the group RT program was developed based on the literature review and the initial meetings with health professionals and institutionalized older people with cognitive impairment. Health professionals noted that these interventions would be beneficial at various levels, emphasizing their role in the quality of life, interaction, social involvement, and well-being of older people in institutional settings.

The program is divided into two parts: the core component (14 sessions) and the follow-up component ( 7 sessions). The core component is developed over a seven-week period, with two weekly sessions of up to 60 minutes each. It is complemented by a follow-up component to be developed during seven weeks, with one weekly session of up to 60 minutes. Each session focuses on a topic related to participants' lives, namely their childhood and family, school, work, travels, festive seasons, and other important moments (Table 1). In some sessions, suggestions are made of complementary activities to be developed in institutional settings. However, professionals should focus on participants' autobiographical memoirs, regardless of the nature of the activity to be performed. 
Table 1

$R T$ program sessions (first draft)

\begin{tabular}{ll}
\hline CORE COMPONENT & FOLLOW-UP COMPONENT \\
\hline $\begin{array}{ll}\text { 1. Presentation of all those involved/background } & \text { 1. Ambitions and dreams } \\
\text { 2. Family } & \text { 2. Days at the beach } \\
\text { 3. First smells/family meals } & \text { 3. Fashion } \\
\text { 4. Childhood games, toys, and friends } & \text { 4. Cultural celebrations: Freedom Day } \\
\text { 5. School days } & \text { 5. Shops and products from another era } \\
\text { 6. Youth } & \text { 6. Anniversaries } \\
\text { 7. Music and songs from another era } & \text { 7. Closing session } \\
\text { 8. Professional life/occupation } & \\
\text { 9. Marriage/partnership and children } & \\
\text { 10. Gardening and agriculture } & \\
\text { 11. Means of communication/information } & \\
\text { 12. Means of transportation, travel, and holidays } & \\
\text { 13. Holidays and festive seasons } & \\
\text { 14. Closing session } & \end{array}$
\end{tabular}

During this process, a digital platform was created to gather audiovisual content to be used in some of the sessions. This idea arose from the need to have an intervention that could be replicable in different institutional settings. During Phase II (modeling), most experts agreed with the structure, duration, topics/ activities proposed, and clarity of the contents in the core and follow-up components of the program (Table 2). Experts considered that this program had potential for replication in different institutional settings.

Table 2

Experts' assessment of the program in Phase II (modelling)

\begin{tabular}{|c|c|c|c|c|c|c|}
\hline \multicolumn{2}{|c|}{ QUESTION } & \multirow{2}{*}{$\begin{array}{c}\text { Strongly disagree } \\
0 \%\end{array}$} & \multirow{2}{*}{$\begin{array}{c}\text { Disagree } \\
0 \%\end{array}$} & \multirow{2}{*}{$\begin{array}{c}\text { Neither agree } \\
\text { nor disagree }\end{array}$} & \multirow{2}{*}{$\begin{array}{c}\text { Agree } \\
46.15 \%\end{array}$} & \multirow{2}{*}{$\begin{array}{c}\text { Strongly agree } \\
53.85 \%\end{array}$} \\
\hline \multirow{8}{*}{ 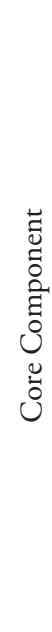 } & Is the program well structured? & & & & & \\
\hline & $\begin{array}{l}\text { Is the duration of the program } \\
\text { adequate? }\end{array}$ & $0 \%$ & $0 \%$ & $7.69 \%$ & $46.15 \%$ & $46.15 \%$ \\
\hline & $\begin{array}{l}\text { Are the topics covered in the program } \\
\text { appropriate to the target audience? }\end{array}$ & $0 \%$ & $0 \%$ & $0 \%$ & $69.23 \%$ & $30.77 \%$ \\
\hline & $\begin{array}{l}\text { Are the contents of the program } \\
\text { appropriate to the target audience? }\end{array}$ & $0 \%$ & $0 \%$ & $0 \%$ & $53.85 \%$ & $46.15 \%$ \\
\hline & $\begin{array}{l}\text { Are the program sessions well or- } \\
\text { ganized? }\end{array}$ & $0 \%$ & $0 \%$ & $15.38 \%$ & $23.07 \%$ & $61.54 \%$ \\
\hline & Are the program sessions clear? & $0 \%$ & $0 \%$ & $0 \%$ & $15.38 \%$ & $84.62 \%$ \\
\hline & $\begin{array}{l}\text { Do the program sessions offer an } \\
\text { appropriate variety of activities? }\end{array}$ & $0 \%$ & $0 \%$ & $0 \%$ & $30.77 \%$ & $69.23 \%$ \\
\hline & $\begin{array}{l}\text { Does the core component have a } \\
\text { potential for replication? }\end{array}$ & $0 \%$ & $0 \%$ & $0 \%$ & $38.46 \%$ & $61.54 \%$ \\
\hline
\end{tabular}




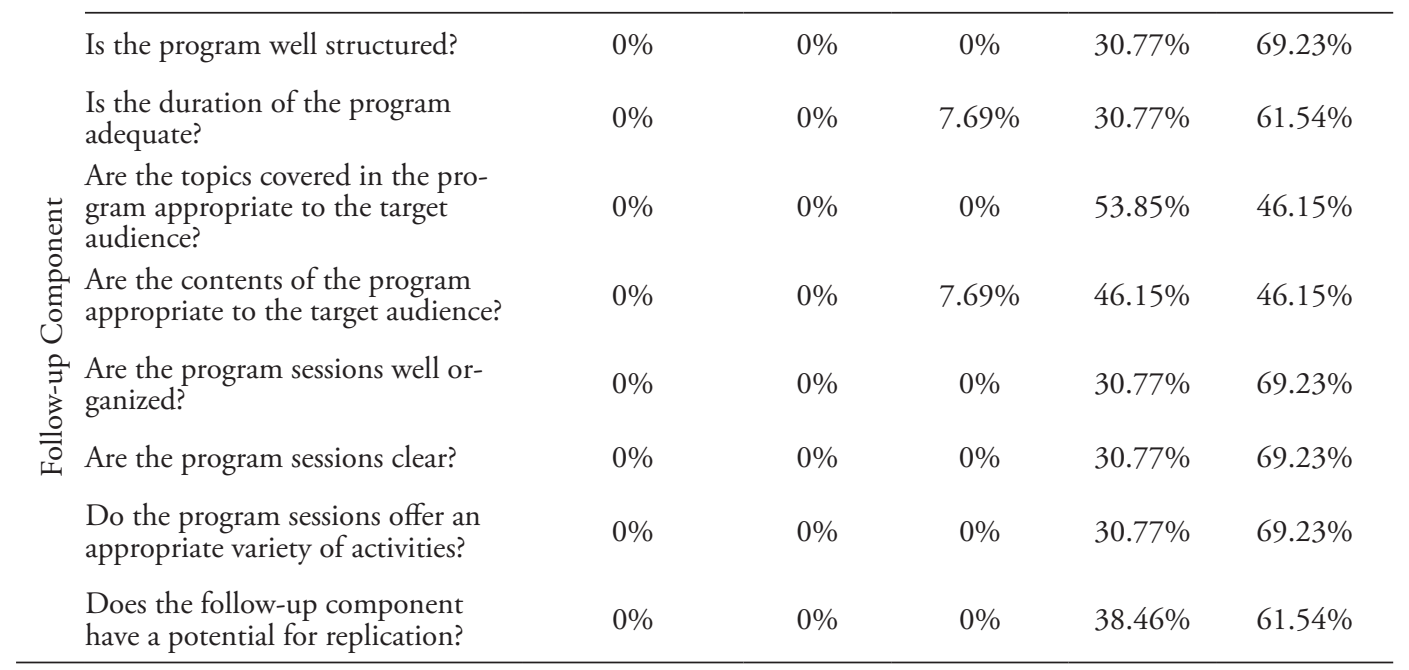

Based on the experts' opinions, a second draft of the RT program was developed. Both focus groups emphasized a concern about how sessions would be conducted and which would be the underlying principles. Therefore, its structure was changed and a more visually appealing and user-friendly guide was created for the session facilitators. Based on the literature review, an introduction was added to the core and follow-up components to contextualize the importance of this type of interventions in institutionalized older people with cognitive impairment, particularly in reducing depressive symptoms and promoting their quality of life and well-being. A chapter was also added to describe the program structure and sessions, underlining the key aspects of its implementation. In total, the time reserved for each session included 15 minutes for presentation, 35 minutes for discussion of topics, and 10 minutes for conclusion, although these are not strict times. During each session, the facilitator should maximize the time available and focus on the discussion of each topic.

Based on various experts' suggestions, new complementary activities were integrated into the program, emphasizing the need to promote social involvement and interaction during sessions, as well as the performance of practical activities. Following the experts' suggestion, activities aimed at the multisensory stimulation of older people were integrated into several sessions.

Some of the topics addressed were slightly altered, particularly the sessions on marriage, partnership, and children and on songs of another era, so that they could be developed with heterogeneous groups with different life paths and personal characteristics. Alternative proposals were included in some sessions so that the program facilitators could work around issues that evoke less positive memories or issues that are not relevant to participants' life stories. Finally, most experts suggested that a moment of relaxation using abdominal breathing techniques should be included at the end of each session.

In the same line as the experts' assessment from Phase II, the nurses/facilitators from Phase III (field testing) considered that the implementation of this type of interventions in institutional settings is an added value both for older people and professionals. The data collected from the questionnaire show that all nurses agreed with the structure, topics, and contents of the core component of the program, and emphasized the clarity, variety, and organization of the component (Table 3). 
Table 3

Nurses' assessment of the program in Phase III (field testing)

\begin{tabular}{|c|c|c|c|c|c|c|}
\hline \multicolumn{2}{|c|}{ QUESTION } & \multirow{2}{*}{$\begin{array}{l}\text { Strongly } \\
\text { disagree }\end{array}$} & \multirow{2}{*}{$\begin{array}{c}\text { Disagree } \\
0 \%\end{array}$} & \multirow{2}{*}{$\begin{array}{c}\text { Neither agree } \\
\text { nor disagree }\end{array}$} & \multirow{2}{*}{$\begin{array}{l}\text { Agree } \\
0 \%\end{array}$} & \multirow{2}{*}{$\begin{array}{c}\text { Strongly agree } \\
100 \%\end{array}$} \\
\hline \multirow{8}{*}{ 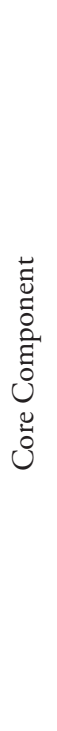 } & Is the program well structured? & & & & & \\
\hline & $\begin{array}{l}\text { Is the duration of the program } \\
\text { adequate? }\end{array}$ & $0 \%$ & $0 \%$ & $14.29 \%$ & $42.86 \%$ & $42.86 \%$ \\
\hline & $\begin{array}{l}\text { Are the topics covered in the } \\
\text { program appropriate to the } \\
\text { target audience? }\end{array}$ & $0 \%$ & $0 \%$ & $0 \%$ & $0 \%$ & $100 \%$ \\
\hline & $\begin{array}{l}\text { Are the contents of the program } \\
\text { appropriate to the target audi- } \\
\text { ence? }\end{array}$ & $0 \%$ & $0 \%$ & $0 \%$ & $14.29 \%$ & $85.71 \%$ \\
\hline & $\begin{array}{l}\text { Are the program sessions well } \\
\text { organized? }\end{array}$ & $0 \%$ & $0 \%$ & $0 \%$ & $0 \%$ & $100 \%$ \\
\hline & Are the program sessions clear? & $0 \%$ & $0 \%$ & $0 \%$ & $28.57 \%$ & $71.43 \%$ \\
\hline & $\begin{array}{l}\text { Do the program sessions offer } \\
\text { an appropriate variety of activ- } \\
\text { ities? }\end{array}$ & $0 \%$ & $0 \%$ & $14.29 \%$ & $28.57 \%$ & $57.14 \%$ \\
\hline & $\begin{array}{l}\text { Does the core component have } \\
\text { a potential for replication? }\end{array}$ & $0 \%$ & $0 \%$ & $14.29 \%$ & $28.57 \%$ & $57.14 \%$ \\
\hline \multirow{8}{*}{ 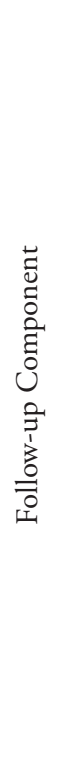 } & Is the program well structured? & $0 \%$ & $0 \%$ & $0 \%$ & $0 \%$ & $100 \%$ \\
\hline & $\begin{array}{l}\text { Is the duration of the program } \\
\text { adequate? }\end{array}$ & $0 \%$ & $0 \%$ & $14.29 \%$ & $14.29 \%$ & $71.43 \%$ \\
\hline & $\begin{array}{l}\text { Are the topics covered in the } \\
\text { program appropriate to the } \\
\text { target audience? }\end{array}$ & $0 \%$ & $0 \%$ & $0 \%$ & $0 \%$ & $100 \%$ \\
\hline & $\begin{array}{l}\text { Are the contents of the program } \\
\text { appropriate to the target audi- } \\
\text { ence? }\end{array}$ & $0 \%$ & $0 \%$ & $0 \%$ & $0 \%$ & $100 \%$ \\
\hline & $\begin{array}{l}\text { Are the program sessions well } \\
\text { organized? }\end{array}$ & $0 \%$ & $0 \%$ & $0 \%$ & $14.29 \%$ & $85.71 \%$ \\
\hline & Are the program sessions clear? & $0 \%$ & $0 \%$ & $0 \%$ & $42.86 \%$ & $57.14 \%$ \\
\hline & $\begin{array}{l}\text { Do the program sessions offer } \\
\text { an appropriate variety of activ- } \\
\text { ities? }\end{array}$ & $0 \%$ & $0 \%$ & $14.29 \%$ & $42.86 \%$ & $42.86 \%$ \\
\hline & $\begin{array}{l}\text { Does the follow-up component } \\
\text { have a potential for replication? }\end{array}$ & $0 \%$ & $0 \%$ & $0 \%$ & $42.86 \%$ & $57.14 \%$ \\
\hline
\end{tabular}

Older people considered the sessions and activities to be pleasant and interesting. In fact, other older adults at the institution showed interest in participating in the sessions. A significant percentage of the older people who parcipated in the study agreed with the structure, topics, and activities of the program (Table 4). 
Table 4

Older people's assessment of the program in Phase III (field testing)

\begin{tabular}{|c|c|c|c|c|c|}
\hline QUESTION & $\begin{array}{l}\text { Strongly } \\
\text { disagree }\end{array}$ & Disagree & $\begin{array}{l}\text { Neither agree } \\
\text { nor disagree }\end{array}$ & Agree & $\begin{array}{l}\text { Strongly } \\
\text { agree }\end{array}$ \\
\hline Is the program well structured? & $0 \%$ & $0 \%$ & $0 \%$ & $44.44 \%$ & $55.56 \%$ \\
\hline Is the duration of the program adequate? & $0 \%$ & $22.22 \%$ & $44.44 \%$ & $33.33 \%$ & $0 \%$ \\
\hline $\begin{array}{l}\text { Do I find the topics covered in the program inter- } \\
\text { esting and pleasant? }\end{array}$ & $0 \%$ & $0 \%$ & $0 \%$ & $33.3 \%$ & $66.67 \%$ \\
\hline Are the proposed activities exciting and engaging? & $0 \%$ & $0 \%$ & $11.11 \%$ & $22.22 \%$ & $66.67 \%$ \\
\hline $\begin{array}{l}\text { Do the images and objects used facilitate my } \\
\text { memories? }\end{array}$ & $0 \%$ & $0 \%$ & $11.11 \%$ & $11.11 \%$ & $77.78 \%$ \\
\hline $\begin{array}{l}\text { Was it important for you to remember past mo- } \\
\text { ments of your life? }\end{array}$ & $0 \%$ & $0 \%$ & $0 \%$ & $33.33 \%$ & $66.67 \%$ \\
\hline $\begin{array}{l}\text { Would you like to participate in more programs } \\
\text { like this? }\end{array}$ & $0 \%$ & $0 \%$ & $0 \%$ & $33.33 \%$ & $66.67 \%$ \\
\hline
\end{tabular}

The majority of older people found it important to remember past moments and expressed their desire to participate in similar programs. In a less consensual manner, the older people considered that the program was too short and suggested that more sessions should be included in this phase, which would increase older people's satisfaction with the program. Based on the opinions of potential RT program users and the research team's observations in practical settings, some sentences and terminology were reformulated and the layout of both the guide and digital platform was changed so as to improve users' experience.

The implementation of an RT program should follow certain guidelines in order to ensure the quality and effectiveness of the intervention, a concern which had already been expressed by some experts in Phase II. These concerns also emerged during field testing, where nurses had difficulties in dealing with specific situations related to the sessions and group dynamics. To overcome this, a section describing the key RT principles was added to the guide with the purpose of guiding and assisting the facilitators.

During Phase IV (consensus conference), based on the analysis of similarities found throughout the different phases, minor semantic and structural changes were made in order to fill in gaps or apply suggestions for clarification pointed out in previous phases. However, two aspects stand out from the group discussion: the duration and topics of the program.

With regard to its duration, even though some experts considered it as potentially excessive (Phase II), the program users thought otherwise (Phase III). This aspect reinforced the need to include complementary activities in some program sessions which evoke the essence of reminiscence and can be developed in other institutional settings. Thus, when users express a clear desire to participate in this type of intervention for a longer period of time, professionals should have a set of useful materials to plan and implement reminiscence activities.

With regard to the topics, as in the initial analysis (Phase I), health professionals identified the existence of topics that were not relevant to potential users as a potential weakness of this program. However, the topics that emerged from the consultation with a heterogeneous group of potential users from different institutional settings (Phase III) proved to match those proposed by the research team. In addition, during this phase, the target population showed a great acceptance of the topics. The consensus conference was the final phase in the process of development and validation of the RT program. A final version was developed, in the form of a guide with 21 sessions, and complemented with support materials.

\section{Discussion}

Given the lack of a structured RT intervention model, the program and the materials developed in this study emerge as new con- 
tributions to clinical practice, with potential theoretical and research implications. This process is recommended by the Medical Research Council (Craig et al., 2008) as a way of helping researchers to deal with factors that may compromise the final assessment of the effectiveness of an intervention, such as barriers related to the acceptability, compliance, and applicability of an intervention, participant retention, and results below expectations.

The focus groups, interviews, and field testing served as platform for all potential RT program users (older persons in institutional settings and health professionals) to give their opinions on the requirements and expectations for this type of intervention. Furthermore, the assessment made by the experts with multidisciplinary training and recognized experience in the implementation of therapeutic interventions was essential to restructure and reformulate the original version to ensure the suitability and adaptability of the developed program.

Nevertheless, this study had some limitations. Even though the implementation of the Medical Research Council guidelines for the development of complex interventions (Craig et al., 2008) is a good practice in clinical research, this process does not guarantee the effectiveness of the intervention or the lack of barriers to the design, implementation, or evaluation of future studies on a larger scale. It should be noted that, during the process of development and validation of the RT program, none of the relevant outcomes found in the literature were assessed (e.g., cognition, quality of life, and depressive symptoms), so there is no indication of the potential effectiveness of the intervention in these areas.

However, a consensus was reached among experts and potential program users regarding the relevance and need for this type of intervention in institutional settings. Similarly, the researchers observed moments of well-being, social engagement, enjoyment, and development of communication skills among participants during the field testing phase. These observations are in line with some of the results found in the literature on the potential effectiveness of RT in areas such as cognition, quality of life, and depressive symptoms among older people with cognitive impairment in institutional settings. To this end, a pilot study should be conducted to provide evidence about the effectiveness of the RT program which was developed in this study.

\section{Conclusion}

Based on the opinions and suggestions of both multidisciplinary experts with recognized experience in this area and potential users, the developed RT program took into account the most relevant characteristics and needs of older people with cognitive impairment in institutional settings. The validation process resulted in a structured program with 21 sessions, divided into two parts - a core component and a follow-up component. However, a pilot study should be conducted to assess the effectiveness of the final version of this RT program, which will be the next step for the research team.

\section{References}

Berg, A., Sadowski, K., Beyrodt, M., Hanns, S., Zimmermann, M., Langer, G., ... Behrens, J. (2010). Snoezelen, structured reminiscence therapy and 10-minutes activation in long term care residents with dementia (WISDE): Study protocol of a cluster randomized controlled trial. BMC geriatrics, 10(1), 1. doi:10.1186/1471-2318-10-5

Bohlmeijer, E., Roemer, M., Cuijpers, P., \& Smit, F. (2007). The effects of reminiscence on psychological well-being in older adults: A meta-analysis. Aging \& Mental Health, 11(3), 291-300. doi:10.1080/13607860600963547

Brooke, P., \& Bullock, R. (1999). Validation of a 6 item cognitive impairment test with a view to primary care usage. International Journal of Geriatric Psychiatry, 14(11), 936-940. doi:10.1002/(SICI)10991166(199911)14:11<936::AID-GPS39>3.0.CO;2-1

Cotelli, M., Manenti, R., \& Zanetti, O. (2012). Reminiscence therapy in dementia: A review. Maturitas, 72(3), 203-205. doi:10.1016/j.maturitas.2012.04.008

Craig, P., Dieppe, P., Macintyre, S., Michie, S., Nazareth, I., \& Petticrew, M. (2008). Developing and evaluating complex interventions: The new medical research council guidance. BMJ, 337, a1655. 
doi:10.1136/bmj.a1655

Direção-Geral da Saúde (2016). Portugal: Saúde mental em números 2015. Retrieved from http:// www.apah.pt/media/publicacoes_tecnicas_sector_ saude_2/Saude_Mental.p

Gonçalves, D. (2006). Estimulação e promoção de memórias autobiográficas especificas como metodologia de diminuição de sintomatologia depressiva em pessoas idosas (Unpublished Master's dissertation). Universidade do Minho, Portugal. Retrieved from http:// hdl.handle.net/1822/6506

Gonçalves, D. C., Albuquerque, P. B., \& Martín, I. (2008). Reminiscência enquanto ferramenta de trabalho com idosos: Vantagens e limitaçôes. Análise Psicológica, 1(26), 101-110. Retrieved from http:// www.scielo.mec.pt/pdf/aps/v26n1/v26n1a08.pdf

Kuske, B., Luck, T., Hanns, S., Matschinger, H., Angermeyer, M. C., Behrens, J., \& Riedel-Heller, S. G. (2009). Training in dementia care: A cluster-randomized controlled trial of a training program for nursing homestaff in Germany. International Psychogeriatrics, 21(2), 295-308. doi:10.1017/ S1041610208008387

Lopes, T. S., Afonso, R., \& Ribeiro, O. M. (2013). Programa de reminiscência simples para pessoas idosas con demência. International Journal of Developmental and Educational Psychology/INFAD Revista de Psicología, 2(1), 107-118. Retrieved from http:// dehesa.unex.es:8080/xmlui/handle/10662/1093
Paiva, D., \& Apóstolo, J. (2015). Estudo de adaptação transcultural e validação do Six Item Cognitive Impairment Test. In J. Apóstolo \& M. Almeida (Eds.), Elderly health care nursing (Mon. ser. 13, pp. 3-18). Retrieved from https:/www.researchgate.net/ publication/282869029_Paiva_Diana_S_Apostolo_Joao_L_A_2015_Estudo_de_adaptacao_transcultural_e_validacao_do_Six_Item_Cognitive_Impairment_Test_In_J_Apostolo_M_Almeida_Eds_ Elderly_Health_Care_Nursing_Monographic_Series_-_He

Stinson, C. K. (2009). Structured group reminiscence: An intervention for older adults. Journal of Continuing Education in Nursing, 40(11), 521-528. doi: 10.3928/00220124-20091023-10

Subramaniam, P., \& Woods, B. (2012). The impact of individual reminiscence therapy for people with dementia: Systematic review. Expert Review of Neurotherapeutics, 12(5), 545-555. doi:10.1586/ ern. 12.35

Webster, J. D., Bohlmeijer, E. T., \& Westerhof, G. J. (2010). Mapping the future of reminiscence: A conceptual guide for research and practice. Research on Aging, 32(4), 527-564. doi:10.1177/0164027510364122

World Health Organization. (2015). First WHO ministerial conference on global action against dementia. Retrieved from http://www.who.int/nmh/conference-on-dementia-march2015-concept-note.pdf 